\title{
ANALYSIS OF SOCIO ECONOMIC DEVELOPMENT OF WOMEN IN PUSHKAR (AJMER)
}

\author{
Monika Sharma ${ }^{1}$ and Monika Kannan ${ }^{2}$ \\ ${ }^{1}$ Research Scholar, ${ }^{2}$ Associate Professor, \\ Dept. of Geography, Sophia Girls' College, Ajmer (Rajasthan) India \\ Email: kannanmonika@gmail.com
}

\begin{abstract}
Socio-economic development and Empowerment of the individual leads to the development and well-being of an individual in all spheres of life. Improved education system is the need of the hour. Development of education and literacy skills would help the people to gain employment opportunity. Employment opportunity helps them generate source of income and raising their standard of living. The study "Analysis of Socio Economic Development of Women in Pushkar (Ajmer) (2011)", a base of which is data collection through Census of India and also through official websites. Different indicators like sex ratio, literacy rate, working participation are taken for socio economic development of women. In Socio-economic development of society, many factors plays significant role in which educational attainment is considered as an important one. Education creates power to think rationally about every element in human beings including females. With education women can perform their various family roles that are daughter, wife, and mother with perfection as well as can become economically self-reliant and consequently achieve the proper status in society equivalent to men. But still inequalities can be finding in male and female literacy. Females are lagging behind in literacy than males. Active participation of women in economic activities is essential for the overall development of any economy. The study presents correlation between female literacy rate and women work participation rate. Karl Pearson method has been adopted to find out correlation between female literacy rate and women work participation rate in the study area. The correlation matrix between female literacy rate and women work participation rate shows strong and negative correlation.
\end{abstract}

Key words: Empowerment, Literacy, Sex Ratio, Work participation, Karl Pearson Correlation.

\section{Introduction}

The word women is a symbol of an idea, knowledge, moral, sacrifice, affection and cooperation. A country is said to be developed only when there is no discrimination between man and woman, they enjoy equal status and they work together. A great woman, Eleanor Roosevelt, once said, "A woman is like a tea bag- you can't tell how strong she is until she steps into hot water". Woman has many qualities that allow them to think and act rationally when men strike at first sign of doubt. Women have ability to create life and create beauty. Every woman has ability to achieve anything through hard work, dedication, love, trust and faith. The position of women deteriorated during late Vedic Age. Women were made victims of social issues like child marriage and dowry system. Indian women are facing many social problems regarding gender inequality, low mobility, illiteracy, female infanticide, high family responsibility and so on. Economic growth of India is hindered because women did not have much freedom to make choices and decision of their own. Though, of late, Government of India and State Governments adopted various schemes in order to create space for the development of women. According to Global Human Development Report, 2013, India ranked $132^{\text {nd }}$ among 148 countries all over the world in terms of gender inequalities. It may be propounded that both gender equality and women empowerment constitute the vital force to bring about transfiguration revolution for achieving desired socio economic progress of India. Women are an important part of today's life as they participate in various social and cultural functions. Woman has proved themselves in every field, whether in the past, in the present and has the mindset to do so in the future. Under 
the given circumstances, we need to deeply consider and discuss how our cultural, traditional social rules affect women empowerment so that the same can be changed.

\section{Objectives}

The major objectives of the study are:

- To study spatial patterns of female literacy rate and sex ratio in Pushkar.

- To present a women work participation scenario of Pushkar (2011).

- To examine correlation between female literacy rate and women work participation rate in the study area.

- To contribute in creating public awareness to invoke women participation in community and society more effectively; and to prepare them to be good women leaders.

\section{Study Area}

Pushkar is a town in the district of Ajmer which lies in the state of Rajasthan in India. It is about $10 \mathrm{~km}$ from Ajmer. Aravalli separates Pushkar from Ajmer. It is situated at the latitude of $26.5^{0}$ North and the longitude of $74.55^{\circ}$ East. Like most of the desert towns, Pushkar experiences semi-arid with extremes of dry and hot summers and cold and freezing winters. May and June are the hottest months with temperature of $45^{\circ} \mathrm{C}$ while January is the coldest month with $7^{0}-8^{0} \mathrm{C}$ of temperature. According to census 2011, 21,626 people lives in Pushkar out of which 11,335 were males and 10,291 were females. Population has increased by 46.2 percent in last 10 years. It recorded literacy of 79.11 percent of which male has literacy of 88.24 percent and female literacy is 69.07 percent. 34.9 percent of total population of the city constitutes the working population of which main workers comprises 84 percent of population whereas marginal workers comprise 16 percent of population. Tourism and cattle fair is the main economic source. Garment manufacturing is an important industrial activity. Traditional handicrafts, Gulkand, Rose oil, Rose water etc. The production of handmade materials like clothes, bags, carpets etc. for sale and export has bloomed. Its main festivals and landmarks are Pushkar Fair, Sikh Gurudwara, Pushkar Lake, Brahma Temple Savitri Temple, Tejaji Fair.

Figure 01: Location Map of Study Region

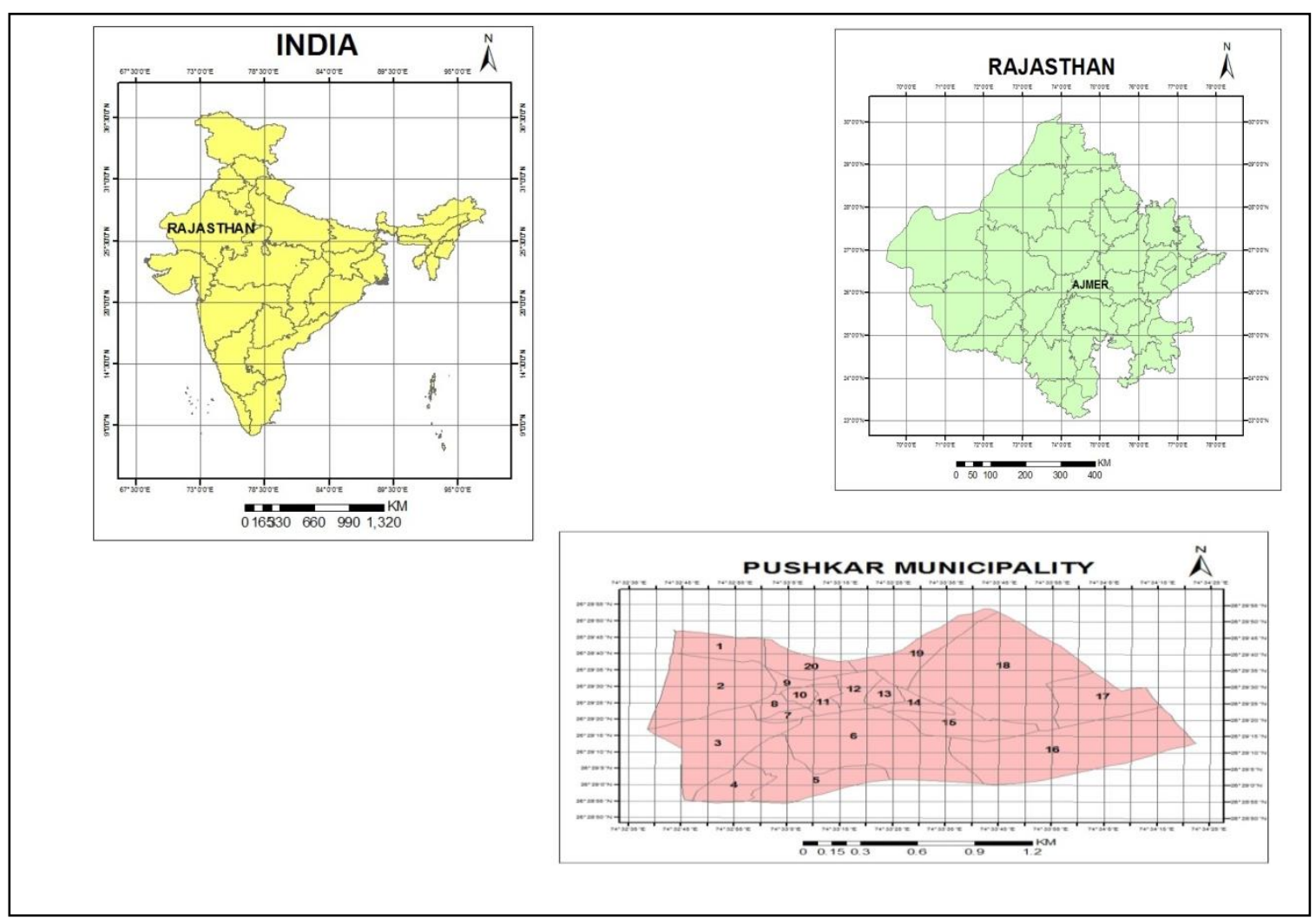




\section{Methodology}

The main source to obtain necessary data for present study is secondary data. The present study is based on secondary data collected by Census of India 2011. Census of India is the main source of information on population tables provided in the A and B series. Karl Pearson Correlation method has been used to analyze the data. This method is used in calculating the correlation between the two variables; which are female literacy rate and women work participation rate in Pushkar. This method is useful in the calculation of correlation between female literacy rate and women work participation rate in Pushkar.

$$
r=\frac{\Sigma x y}{\sqrt{x^{2} * y^{2}}}
$$

The spatial as well non-spatial data was taken consideration to prepare thematic maps and data tabulation. The Pushkar ward boundary was digitized and analytical maps were made.

Figure 02: Sources of Data Collection

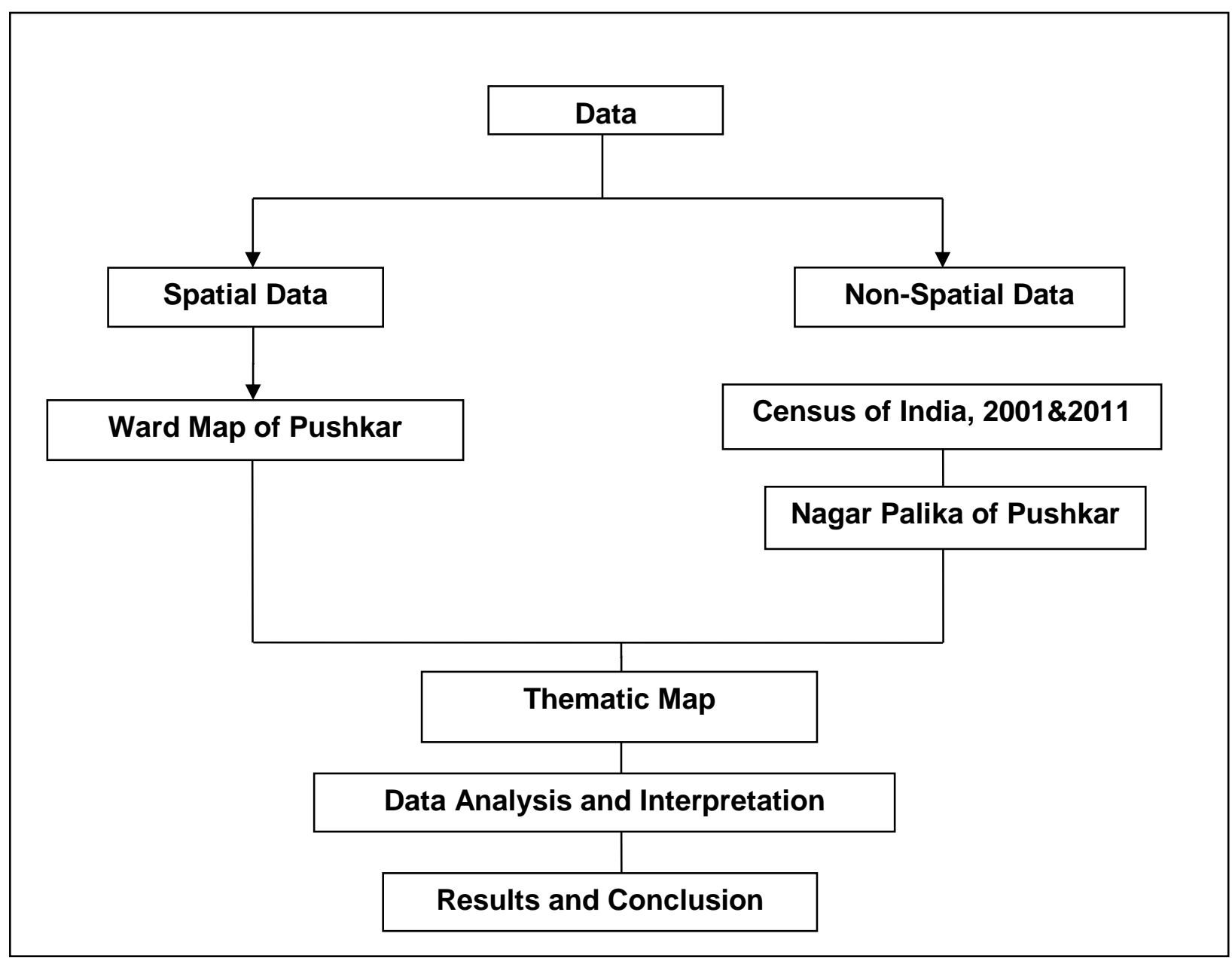

\section{Result and discussion}

The demographic data was analyzed to understand which wards in Pushkar had more sex ration, where the literacy rate was high and whether there exists a relationship between literacy levels and work participation rates amongst woman in the region. According to census 2011, Pushkar has a population of 21,626 of which 11,335 were males and 10,291 were females. The following table shows the Sex Ratio and Literacy levels in Pushkar in the year 2011, to monitor the decadal changes in the population (Table 1). 
Table 01: Ward Wise Sex Ratio and Literacy Rate of Females (2011)

\begin{tabular}{|c|c|c|}
\hline Wards of Pushkar & Sex Ratio & Literacy Rate ( percent) \\
\hline 1 & 969 & 56.00 \\
\hline 2 & 919 & 52.00 \\
\hline 3 & 868 & 84.00 \\
\hline 4 & 839 & 61.00 \\
\hline 5 & 822 & 91.00 \\
\hline 6 & 948 & 91.00 \\
\hline 7 & 978 & 77.00 \\
\hline 8 & 1066 & 81.00 \\
\hline 9 & 969 & 83.00 \\
\hline 10 & 932 & 90.00 \\
\hline 11 & 893 & 83.00 \\
\hline 12 & 901 & 85.00 \\
\hline 13 & 978 & 79.00 \\
\hline 14 & 821 & 67.00 \\
\hline 15 & 788 & 73.00 \\
\hline 16 & 854 & 68.00 \\
\hline 17 & 950 & 34.00 \\
\hline 18 & 964 & 44.00 \\
\hline 19 & 919 & 42.00 \\
\hline 20 & 849 & 72.00 \\
\hline Total & 908 & 69.10 \\
\hline
\end{tabular}

Source: Census of India, 2011, (www.indikosh.com)

Total about 15 thousand people in the city are literate, among them 6123 are female. As India is a patriarchal society, it is an important factor of low female literacy rate. W-(6) has highest female literacy rate (91 percent) while $\mathrm{W}$-(17) has recorded the lowest female literacy rate. Total 829 people in the ward no.6 are literate, among them 389 are female. 91 percent of female population is literate here. As of 2011 census there are 908 females per 1000 male in the city. Overall sex ratio in the city has increased by 49 females per 1000 male during the years from 2001 to 2011 (Table 1).

Figure 03: Ward Wise Literacy Rate and Sex Ratio of Pushkar (2011)

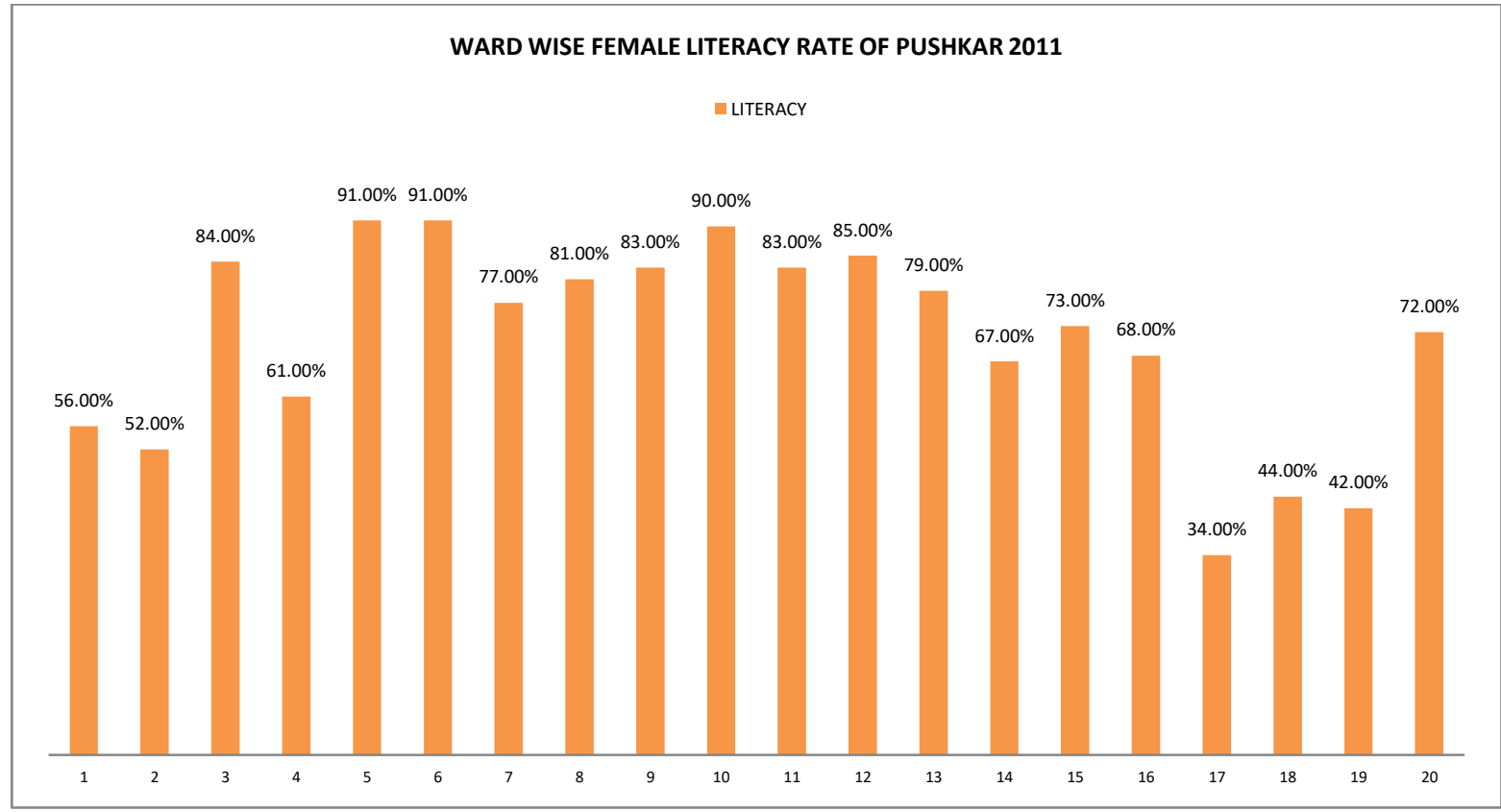




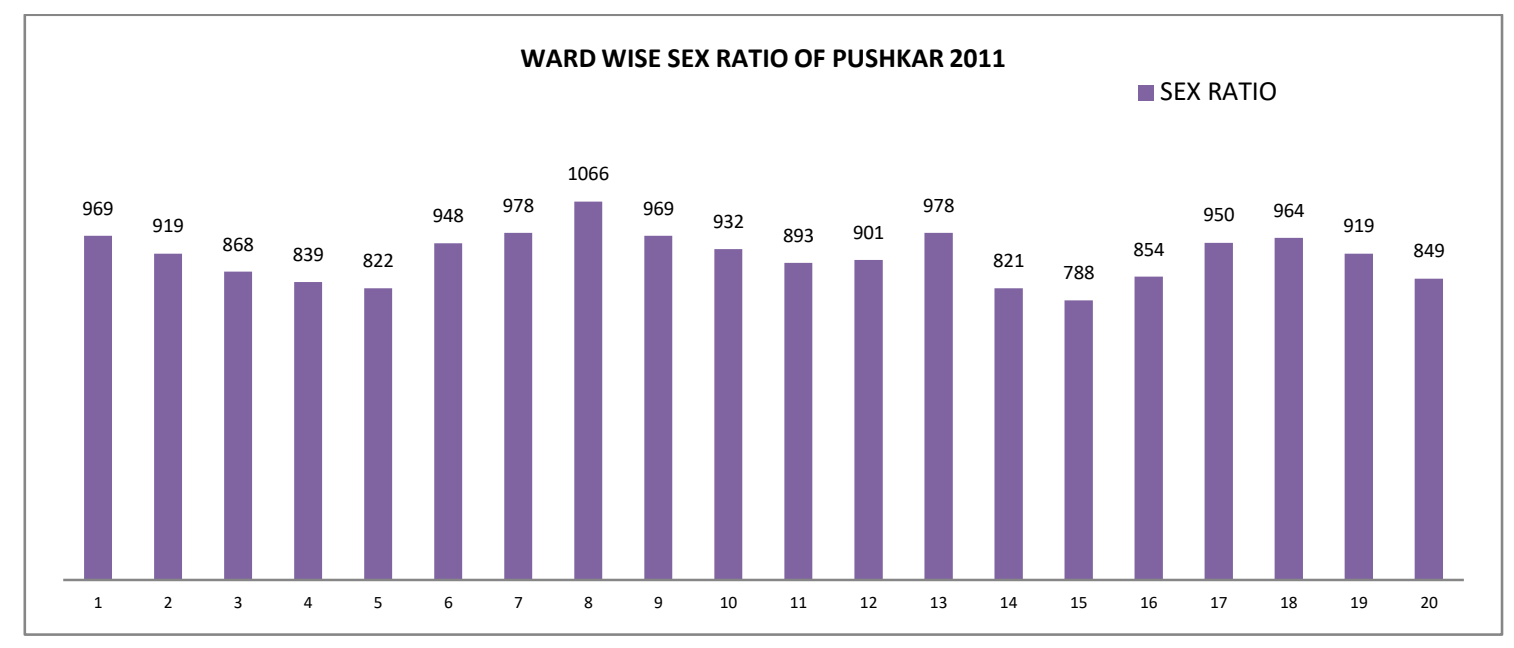

\section{Spatial Pattern of Female Literacy Rate}

Fig. 3 indicates Female literacy rate are high in some wards while low in the others. Ward 5 has highest female literacy rate (91 percent) followed by ward 6 (91 percent) and ward 10 (90 percent) while ward 17 (34 percent) has lowest female literacy rate followed by W-19 (42 percent) and W-8 (44 percent).There are many reasons for low literacy rate - As India is a patriarchal society, it is an important factor of low female literacy rate. Parents do not want to send their girls to long distance. Lack of proper school facility also becomes an obstacle.

Figure 04: Ward Wise Sex Ratio of Pushkar (2011)

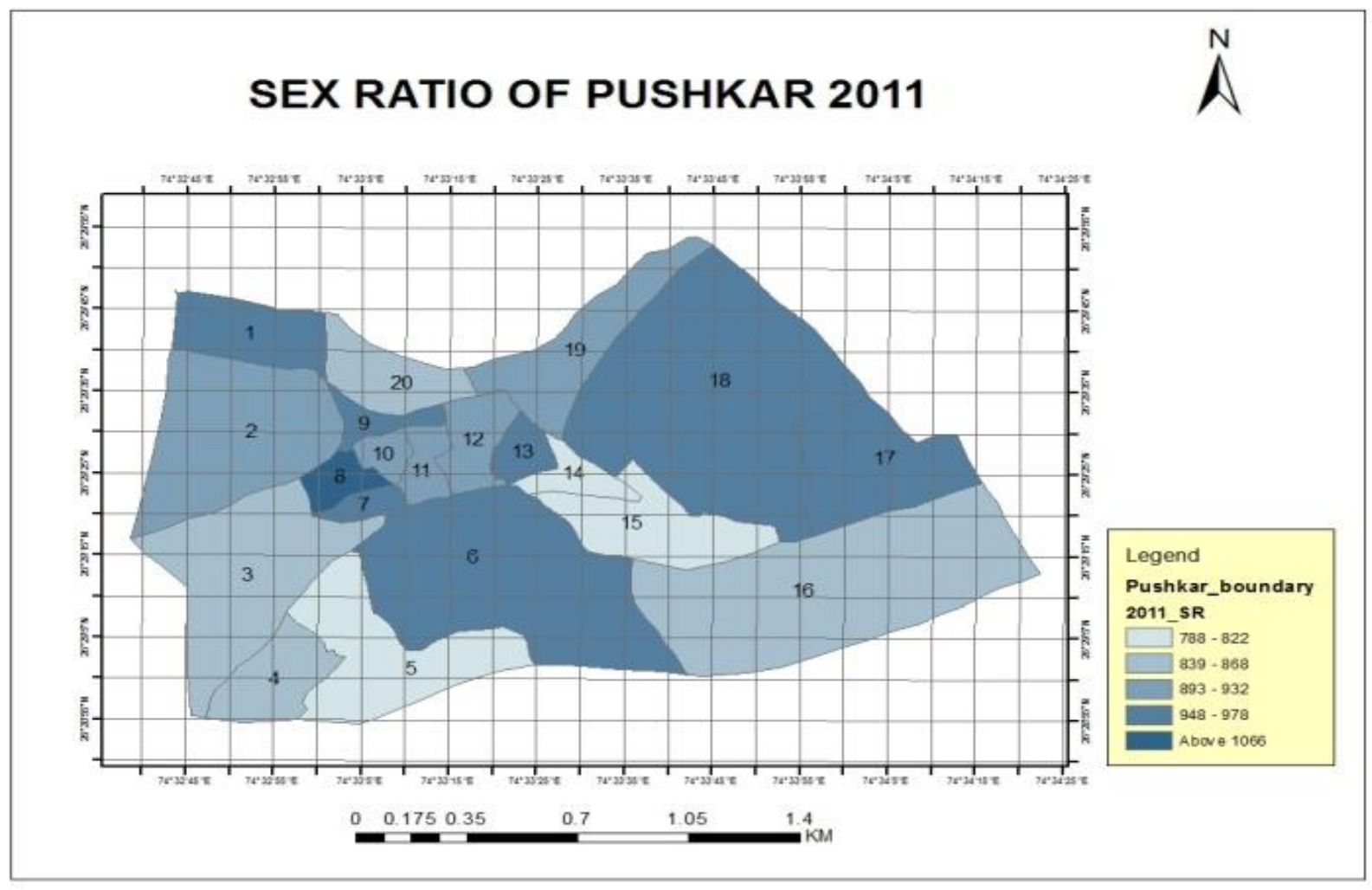

\section{Spatial Pattern of Sex Ratio}

- Wards with High Sex Ratio

W- 8 (1066) has highest sex ratio followed by W-7 \& 13 (978), W-1\&9 (969), W-

18 (964), W-17 (950) indicating high sex ratio (Fig.4).

- Wards with Moderate Sex Ratio 
W-10 (932), W-12 (901), W-19 (919), W-11 (893), W-3 (868), W-6 (854), W-20

(849), W-4 (839) indicating moderate sex ratio (Fig.4).

\section{- Wards with Low Sex Ratio}

W-5 (822), W-14 (821), W-15 (788) indicating low sex ratio (Fig.4).

There are many reasons for low sex ratio - Dowry and young couple's busy schedule leads to decreasing sex ratio. Many couples do not prefer second child. Many people seek female birth as financial, social, emotional and mental a burden on family. The following table presents the women work participation scenario of Pushkar 2011 (Table 2.)

Table 02: Ward Wise Work Participation of Women (2011)

\begin{tabular}{|c|c|c|c|c|}
\hline Wards & $\begin{array}{c}\text { Workers(Among } \\
\text { Total Population) \% }\end{array}$ & $\begin{array}{c}\text { Main Worker (Among } \\
\text { Workers) \% }\end{array}$ & $\begin{array}{c}\text { Marginal Worker } \\
\text { (Among Workers) \% }\end{array}$ & $\begin{array}{c}\text { Non Worker } \\
\text { (Among Total } \\
\text { Population) \% }\end{array}$ \\
\hline 1 & 11.00 & 4.00 & 7.00 & 89.00 \\
\hline 2 & 9.00 & 6.00 & 3.00 & 91.00 \\
\hline 3 & 7.00 & 7.00 & 00 & 93.00 \\
\hline 4 & 23.00 & 20.00 & 00 & 77.00 \\
\hline 5 & 8.00 & 8.00 & 00 & 92.00 \\
\hline 6 & 5.00 & 5.00 & 6.00 & 95.00 \\
\hline 7 & 11.00 & 5.00 & 1.00 & 89.00 \\
\hline 8 & 16.00 & 15.00 & 1.00 & 84.00 \\
\hline 9 & 8.00 & 7.00 & 2.00 & 92.00 \\
\hline 10 & 10.00 & 8.00 & 9.00 & 90.00 \\
\hline 11 & 13.00 & 3.00 & 2.00 & 87.00 \\
\hline 12 & 5.00 & 3.00 & 3.00 & 95.00 \\
\hline 13 & 10.00 & 7.00 & 1.00 & 90.00 \\
\hline 14 & 6.00 & 5.00 & 11.00 & 94.00 \\
\hline 15 & 20.00 & 9.00 & 3.00 & 80.00 \\
\hline 16 & 20.00 & 16.00 & 7.00 & 80.00 \\
\hline 17 & 36.00 & 29.00 & 1.00 & 64.00 \\
\hline 18 & 11.00 & 10.00 & 24.00 & 89.00 \\
\hline 19 & 25.00 & 1.00 & 00 & 75.00 \\
\hline 20 & 11.00 & 10.00 & 4.40 & 89.00 \\
\hline Total & 14.30 & 9.90 & & 85.70 \\
\hline
\end{tabular}

Source: Census of India, 2011, (www.indikosh.com)

It clearly show from Table 2 that women work participation is very low in Pushkar as per census 2011. There are more female non-workers as compared to workers in Pushkar. Only 14.3 percent are working women, among them 9.9 percent are main and 4.4 percent are marginal workers. 85.50 percent are non-workers (Table 2). There are many reasons for low working participation of women. Lack of equal economic opportunity women drop out of their jobs due to the lack of sufficient and quality jobs in the market, Only males have access to the limited job opportunities. Poor working conditions force women to leave their jobs. For example, safety and adequate facilities at the work place is of major concern. Pushkar has 35 percent (7554) population engaged in either main or marginal works. 14 percent female population is working population.10 percent of total female population are main and 4 percent are marginal workers. W-17 has highest female workers (36 percent), of which 29 percent are main and 7 percent are marginal workers. W-6 \& 12 has lowest female workers (5 percent). W-19 is the only ward which has more female workers engaged in marginal work (24 percent) (Fig.5) 
Table 03: Correlation between Female Literacy Rate and Women Work Participation Rate (2011)

\begin{tabular}{|c||c||c||c||c||c||c||c||}
\hline Wards & $\begin{array}{c}\text { Literacy Rate } \\
(\%)\end{array}$ & $\begin{array}{c}\text { Workers } \\
(\%)\end{array}$ & $\mathbf{X}=\mathbf{X}-\overline{\mathbf{X}}$ & $\mathbf{y}=\mathbf{Y}-\overline{\mathbf{Y}}$ & $\mathbf{x}^{2}$ & $\mathbf{y}^{2}$ & $\mathbf{x y}$ \\
\hline \hline 1 & 56.00 & 11.00 & -14.65 & -2.25 & 214.62 & 5.06 & 32.96 \\
\hline \hline 2 & 52.00 & 9.00 & -18.65 & -4.25 & 347.82 & 18.06 & 79.26 \\
\hline \hline 3 & 84.00 & 7.00 & 13.35 & -6.25 & 178.22 & 39.06 & -83.43 \\
\hline 4 & 61.00 & 23.00 & -9.65 & 9.75 & 93.12 & 95.06 & -94.08 \\
\hline \hline 5 & 91.00 & 8.00 & 20.35 & -5.25 & 414.12 & 27.56 & -106.83 \\
\hline \hline 6 & 91.00 & 5.00 & 20.35 & -8.25 & 414.12 & 68.06 & -167.88 \\
\hline \hline 7 & 77.00 & 11.00 & 6.35 & -2.25 & 40.32 & 5.06 & -14.28 \\
\hline \hline 8 & 81.00 & 16.00 & 10.35 & 2.75 & 107.12 & 7.56 & 28.46 \\
\hline \hline 9 & 83.00 & 8.00 & 12.35 & -5.25 & 152.52 & 27.56 & -64.83 \\
\hline \hline 10 & 90.00 & 10.00 & 19.35 & -3.25 & 374.42 & 10.56 & -62.88 \\
\hline \hline 11 & 83.00 & 13.00 & 12.35 & 0.25 & 152.52 & 0.06 & 3.08 \\
\hline \hline 12 & 85.00 & 5.00 & 14.35 & -8.25 & 205.92 & 68.06 & -118.38 \\
\hline \hline 13 & 79.00 & 10.00 & 8.35 & -3.25 & 69.72 & 10.56 & -27.13 \\
\hline \hline 14 & 67.00 & 6.00 & -3.65 & -7.25 & 13.32 & 52.56 & 26.46 \\
\hline \hline 15 & 73.00 & 20.00 & 2.35 & 6.75 & 5.52 & 45.56 & 15.86 \\
\hline \hline 16 & 68.00 & 20.00 & -2.65 & 6.75 & 7.02 & 45.56 & -17.88 \\
\hline \hline 17 & 34.00 & 36.00 & -36.65 & 22.75 & 1343.22 & 517.56 & -833.78 \\
\hline \hline 18 & 44.00 & 11.00 & -26.65 & -2.25 & 710.22 & 5.06 & 59.96 \\
\hline \hline 19 & 42.00 & 25.00 & -28.65 & 11.75 & 820.82 & 138.06 & -336.63 \\
\hline \hline 20 & 72.00 & 11.00 & 1.35 & -2.25 & 1.82 & 5.06 & -3.03 \\
\hline \hline & $\bar{X}=70.65$ & $\bar{Y}=13.25$ & & & $\sum x^{2}=5666.5$ & $\sum y^{2}=1191.7$ & $\sum x y=-1685$ \\
\hline
\end{tabular}

Source: Census of India, 2011, (www.indikosh.com)

W-17 (36 percent) has more working women followed by W-19 (25 percent), W-4 (23 percent), W-16 (20 percent), W-15 (20 percent). There are 10 wards which have women working participation rate from 8 percent to 16 percent only. W-6 (5 percent) has lowest rate of working women followed by Ward12 (5 percent), W-14 (6 percent), W-3 (7 percent) Fig.5)

$$
r=\frac{\Sigma x y}{\sqrt{x^{2} * y^{2}}}=-0.64
$$

Karl Pearson Correlation method has been used to analyze the data. This method is used in calculating the correlation between the two variables; which are female literacy rate and women work participation rate in Pushkar. It is observed that there is a strong and negative correlation between female literacy rate and women work participation rate i.e. $r=-0.64$. It shows that as literacy increases, the tendency of work decreases and vice versa.

Figure 05: Ward Wise Work Participation of Women in Pushkar (2011)

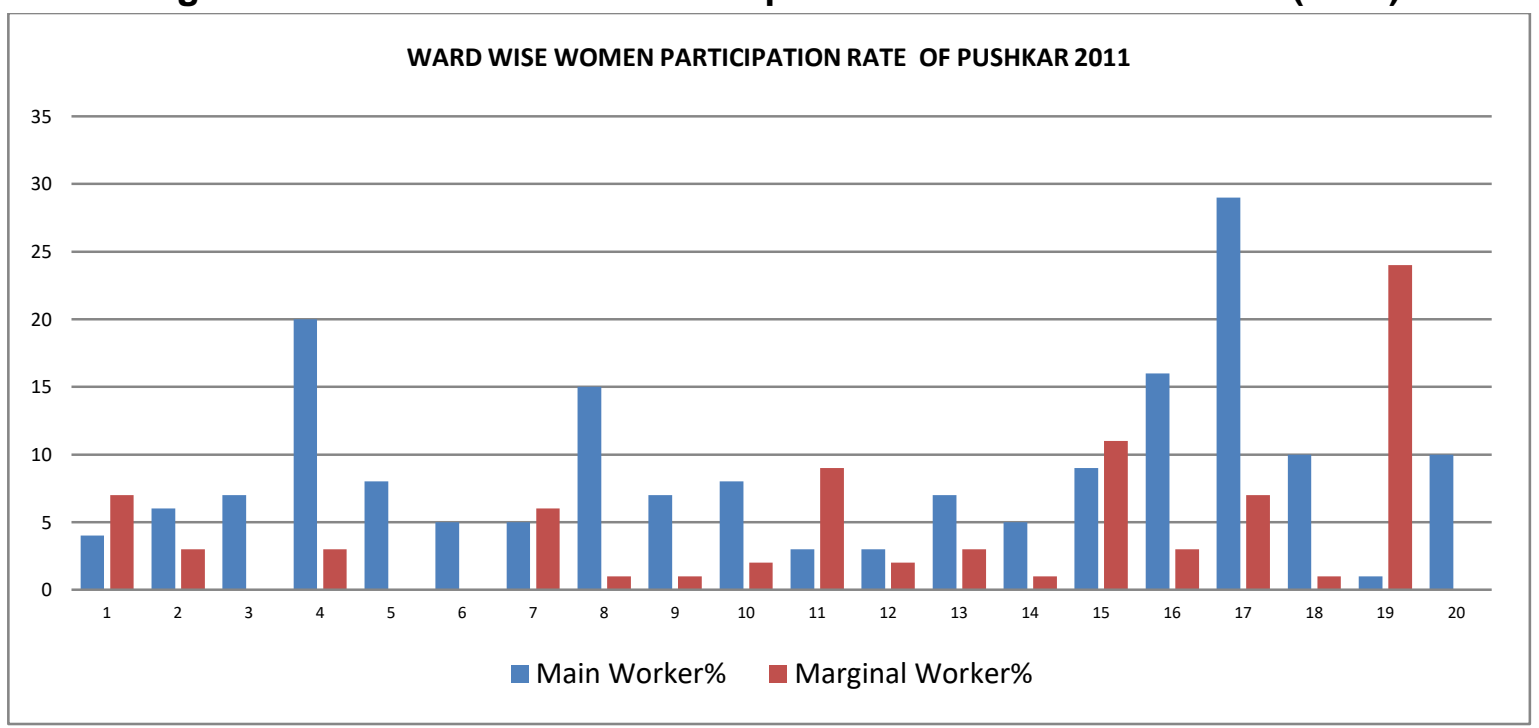


Figure 06: Ward Wise Female Work Participation Rate of Pushkar (2011)

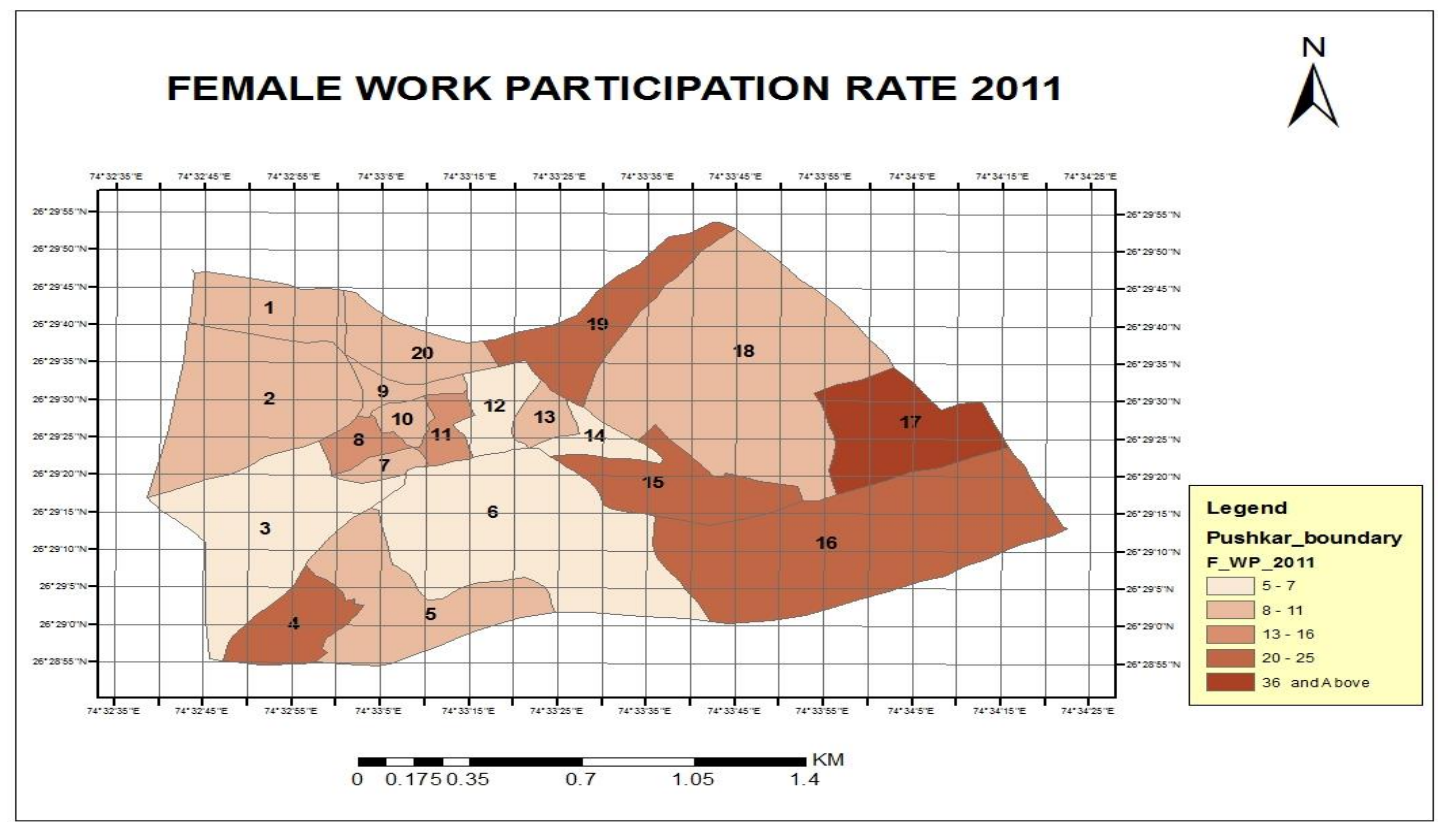

\section{Conclusion}

Literacy and work participation are basic indicators of the level of development achieved by a society. Work participation and literacy lead to a greater awareness and also contributes in improvement of economic and social conditions. The average sex ratio of the region is low. The literacy level is also lower than their male counterpart. The participation of women in the tertiary sector such as medical, teaching, administrative and other official services is lower than the male population. Result of study shows that there is strong and negative correlation between female literacy rate and women work participation i.e. $r=-0.64$. It is very important for government to take initiatives towards girl's education. Many awareness programmes and literacy campaigns should be organized in rural areas for spreading awareness in the matter of girl's education. Empowering women with focus on financial literacy is also important. Providing maternity leave also help women return to their work. Government should take steps towards digital literacy and in creating financial channels, establishing training centers for women increase their work participation.

\section{References}

1. Census of India, (2011.) and Nagar Palika, Pushkar

2. Final Report- Preparation of development and management plan for Historic Temple Complex and Settlements of Rajasthan (prepared for Devasthan Dept., Govt. of Rajasthan, Udaipur

3. Goel Aruna (2004). Education and Socio-economic Perspectives of Women Development and Empowerment, Deep and Deep Publications, pp349.

4. Jumani Usha, (1991). Self-employment for poor rural women, Sage Publication, New Delhi.

5. Khanka S. S., (1998) Entrepreneurship Development, S Chand \& Company Ltd., New Delhi.

6. Kumar Hajira, Jaimon Varghese (2005). Women's Empowerment, Issues, Challenges, and Strategies: A Source Book, Daya Books, Feminism - 578 pages

7. Leela, P. (2000). "Women and the Changing Development Scenario", in Chandu Subba Rao and Francis D. "Development of Weaker Sections", Ravat Publications, Jaipur and New Delhi, pp53-66.

8. Șiddiqui M. Idris (2004). Women Workers, Anamika Pub \& Distributors, pp.76.

9. https://edupediapublications.org/journals/index.php/IJR/

10. www.censusindia.gov.in

11. www.researchgate.net

12. www.travelogyindia.com

13. www.indikosh.com 